\title{
Sustainability of Water Reclamation: Long-Term Recharge with Reclaimed Wastewater Does Not Enhance Antibiotic Resistance in Sediment Bacteria
}

\section{Jean E. McLain ${ }^{1, *}$ and Clinton F. Williams ${ }^{2}$}

1 Water Resources Research Center, University of Arizona Water Resources Research Center, 350 North Campbell Avenue, Tucson, AZ 85719, USA

2 United States Department of Agriculture, Agricultural Research Service, U.S. Arid-Land Agricultural Research Center, 21881 North Cardon Lane, Maricopa, AZ 85138, USA; E-Mail: clinton.williams@ars.usda.gov

* Author to whom correspondence should be addressed; E-Mail: jmclain@cals.arizona.edu; Tel.: +1-520-621-7292; Fax: +1-520-792-8518.

Received: 20 January 2014; in revised form: 4 March 2014 / Accepted: 5 March 2014 /

Published: 12 March 2014

\begin{abstract}
Wastewater reclamation for municipal irrigation is an increasingly attractive option for extending water supplies. However, public health concerns include the potential for development of antibiotic resistance (AR) in environmental bacteria after exposure to residual pharmaceuticals in reclaimed water. Though scientific studies have reported high levels of AR in soils irrigated with wastewater, these works often fail to address the soil resistome, or the natural occurrence of AR. This study compared AR patterns in sediment Enterococcus isolated from water storage basins containing either reclaimed water or groundwater in central Arizona. Resistance to 16 antibiotics was quantified in isolates to a depth of $30 \mathrm{~cm}$. Results reveal high levels of resistance to certain antibiotics, including lincomycin, ciprofloxacin, and erythromycin, exists in sediments regardless of the water source (groundwater, reclaimed water), and higher AR was not detectable in reclaimed water sediments. Furthermore, multiple-antibiotic-resistance (MAR) was substantially reduced in isolates from reclaimed water sediments, compared to freshwater sediment isolates. Comparing the development of AR in sediment bacteria at these two sites will increase awareness of the environmental and public health impacts of using reclaimed water for irrigation of municipal areas, and illustrates the necessity for control sites in studies examining AR development in environmental microbiota.
\end{abstract}


Keywords: Enterococcus; multiple antibiotic resistance; bacterial cultivation; $\mathrm{MIC}_{50}$

\section{Introduction}

A 2000 World Health Organization (WHO) report [1] focused on antibiotic resistance (AR) as one of the most critical human health challenges of the next century and heralded the need for "a global strategy to contain resistance". According to the report, more than two million Americans are infected each year with resistant pathogens and 14,000 die as a result.

Following their use for control of human disease and/or animal husbandry, it is estimated that up to $75 \%$ of antibiotics are excreted unaltered or as metabolites [2]. Unfortunately, most wastewater treatment plants (WWTPs) are not designed for the removal of these micropollutants $[3,4]$ and as a result, residual antibiotics are released into the environment with treated wastewater [5]. Since the late 1990s, many classes of antibiotics have been reported in raw sewage and treated wastewater, including beta-lactams [6], sulfonamides, trimethoprim, and macrolides [7], fluoroquinolones [8], and tetracyclines [9]. Many antibiotics can now easily be detected in natural water sources that receive treated wastewater $[10,11]$, leading to increasing concern regarding the contribution of water reclamation to AR in populations of pathogenic and nonpathogenic environmental microorganisms [12,13].

In addition to the contribution of trace contaminants into the environment via water reclamation, it has also been proposed that the direct input of resistant bacteria into the environment from WWTPs is a source of AR in the environment [14,15]. Yet, many widely used antibiotics were first isolated from naturally-occurring soil fungi and bacteria [16,17] and as a result, most antibiotic-producing strains carry a natural resistance to the compounds that they produce [18]. There is a growing body of evidence that AR is extremely widespread in natural environments, including relatively pristine habitats with no direct exposure to anthropogenic activities [19,20]. For this reason, research studies examining the effects of reclaimed municipal wastewater on the development of AR must consider the natural resistome, AR that exists in absence of the application of wastewater.

Enterococcus species inhabit the gastrointestinal tracts of humans, birds, insects, and reptiles. They are a widely distributed microbial group, frequently isolated from soils, surface waters, and raw plant and animal products, where their intrinsic ruggedness allows them to persist and spread in the environment [21]. Enterococci are also known to appear in foods of animal origin (milk, cheese), and in vegetables because they have an ability to survive heat treatments and adverse environmental conditions [22]. Once viewed as a genus of minimal clinical impact, enterococci have surfaced as organisms of importance due to the emergence of multiple-antibiotic-resistant (MAR) strains that are currently responsible for approximately $12 \%$ of all nosocomial infections in the U.S. $[23,24]$. It has been established that Enterococcus possesses a remarkable capability for horizontal gene transfer, by which bacteria acquire genes from another organism without being its direct offspring. Through this process, bacteria can confer AR to neighboring organisms to relieve the selective pressure produced by antibiotics [25]. The ubiquity of enterococci in human and animal digestive tracts, their medical importance, frequent MAR, and great capacity for horizontal gene transfer make the enterococci an ideal bacterial group for investigating the ecology of AR development. 
This work examined resistance to 16 antibiotics in Enterococcus isolated from sediments of a basin recharged with treated municipal wastewater for more than 20 years. Resistance to the same antibiotics was also assessed in enterococci isolated from sediments of a nearby groundwater-filled pond with no history of exposure to treated wastewater. The objective of this study was to compare levels of AR in the sediments from both sites, to determine the potential for residual antibiotics in treated wastewater to contribute to levels of AR in sediment bacteria.

\section{Materials and Methods}

\subsection{Field Sampling}

Samples were collected in April, 2009 and May, 2010 from recharge basins at the Gilbert Riparian

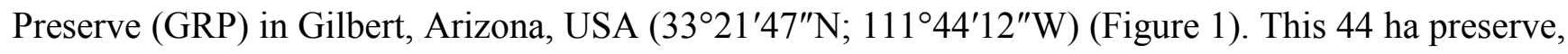
created in 1986, contains 7 recharge basins covering 28 ha. The recharge basins are filled on a rotating basis with tertiary-treated municipal effluent from the City of Gilbert. A control site was established at a pond $\left(33^{\circ} 03^{\prime} 46^{\prime \prime} \mathrm{N} ; 111^{\circ} 58^{\prime} 43^{\prime \prime} \mathrm{W}\right)$ at University of Arizona Maricopa Agricultural Center (MAC) (Figure 1). Since it was created for retention of irrigation water in the 1980s, the MAC pond has been filled solely with groundwater originating from an on-site well. The MAC location was selected as a control site not only because it had never received municipal effluent, but also because the soils beneath the GRP and MAC are geomorphically similar: well-drained soils resulting from the deposition of alluvial materials that have long weathered under arid conditions [26,27].

Figure 1. Location of study sites in Gilbert (GRP) and Maricopa (MAC), Arizona, USA.

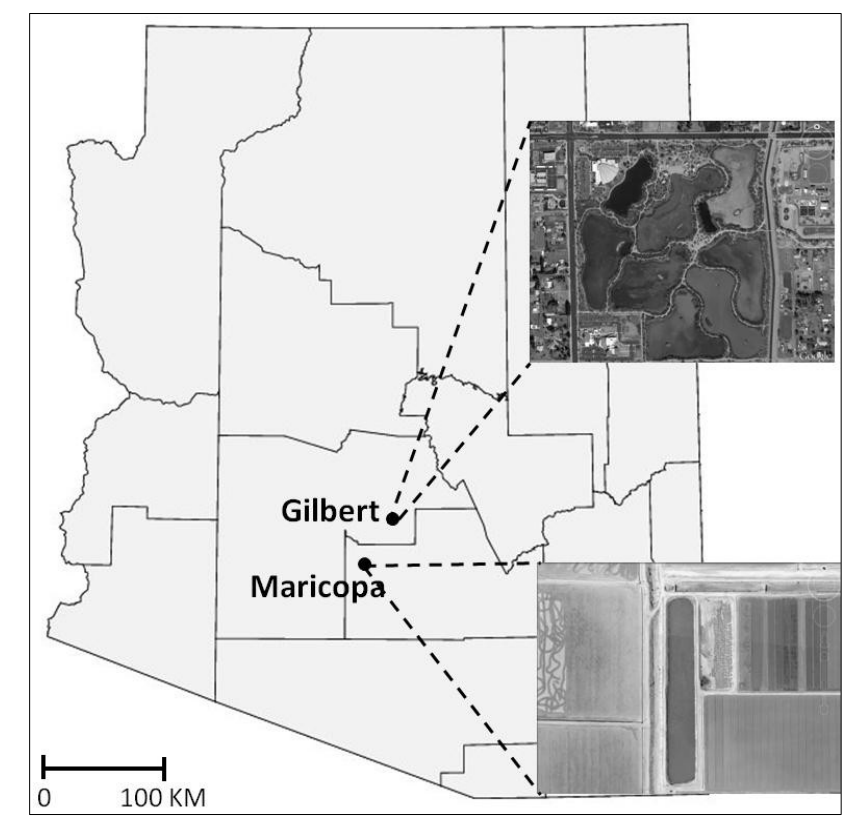

In 2009 and 2010, a total of 106 cores (53 cores per year) were collected across a dry basin at the GRP using a Giddings Hydraulic Soil Probe equipped with a $1.2 \mathrm{~m} \times 9.1 \mathrm{~cm}$ plastic liner (Giddings Machine Company, Windsor, CO, USA). Following extraction, each core was capped on both ends and transported to the laboratory for storage at $4{ }^{\circ} \mathrm{C}$ until analysis. During the same period, a total of 24 control sediment cores (12 cores per year) were collected manually from the MAC site using a 
$2.25 \mathrm{~cm}$ OD stainless steel soil probe (AMS Inc., American Falls, ID, USA) and transported to the laboratory on ice.

During the 2010 collections, grab samples of input water were collected from pipes entering the wetland, at a point approximately $50 \mathrm{~m}$ from the soil sampling sites. Samples were collected in $1 \mathrm{~L}$ volume sterile amber glass bottles, placed on ice, and transported to the laboratory.

\subsection{Laboratory Isolation and Confirmation of Enterococcus}

In the laboratory, cores were subdivided into lengths representing $0-5,10-15$, and $25-50 \mathrm{~cm}$ depths. Using a sterile spatula, approximately $0.5 \mathrm{~g}$ of moist soil was removed from the center of each core and added to a test tube containing 5-7 mL of sterile $\mathrm{BBL}^{\mathrm{TM}}$ Enterococcosel Bile Esculin broth (Becton, Dickinson and Co., Franklin Lakes, NJ, USA) and placed onto a shaking incubator at $37{ }^{\circ} \mathrm{C}$ for presumptive enrichment of total enterococci. Water samples collected during the 2010 field visits underwent the same procedure for selective Enterococcus enrichment, with $1.0 \mathrm{~mL}$ of the inlet water added to each of 10 tubes of $\mathrm{BBL}^{\mathrm{TM}}$ Enterococcosel Bile Esculin broth.

After 24-36 h, aliquots of the enrichment broth were spread onto plates prepared with Enterococcosel Agar (Becton, Dickinson and Company, Franklin Lakes, NJ, USA), a modified bile esculin agar with added sodium azide. Bacterial isolates, presumptive for enterococci, formed a dark brown to black halo surrounding individual colonies. Following $24-36 \mathrm{~h}$ of incubation at $37{ }^{\circ} \mathrm{C}$, isolates from the agar plates with the distinctive black halo were selected for confirmatory screening by polymerase chain reaction (PCR).

For confirmatory analysis, isolates of presumptive Enterococcus were grown overnight in trypticase soy broth. Pellets were washed repeatedly and used as a template for analysis by PCR, using primers specific for the 23S rRNA gene of enterococci [28]. PCR reactions contained $900 \mathrm{nM}$ of the forward primer (5'-AGA AAT TCC AAA CGA ACT TG-3') and $300 \mathrm{nM}$ of the reverse primer (5'-CAG TGC TCT ACC TCC ATC ATT-3'), $12.5 \mu \mathrm{L}$ Go Taq Green Master Mix (Promega Corp., Madison, WI, USA), $1.0 \mu \mathrm{L}$ of the bacterial pellet, and sterile water to $25 \mu \mathrm{L}$. Reactions were run on a Veriti ${ }^{\circledR}$ Thermocycler (Applied Biosystems, Foster City, CA, USA) using a program consisting of the initial denaturation at $94{ }^{\circ} \mathrm{C}$ for $15 \mathrm{~min}$, and 40 cycles with a denaturation at $95{ }^{\circ} \mathrm{C}$ for $15 \mathrm{~s}$ and annealing at $60{ }^{\circ} \mathrm{C}$ for $60 \mathrm{~s}$. Each PCR run included positive and negative control tubes, with template Enterococcus faecalis (ATCC \#29212) and nuclease-free water, respectively. Amplification product was detected by electrophoresis in a $2 \%$ agarose gel, stained with SYBR ${ }^{\mathrm{TM}}$ Safe DNA Gel Stain (Invitrogen Life Technologies, Carlsbad, CA, USA) and visualized by transillumination by UV light. Presence of a DNA fragment of $71 \mathrm{bp}$ indicated positivity for Enterococcus.

\subsection{Screening of Isolates for Antibiotic Sensitivity}

Following PCR confirmation, a sample of each isolate was added to $5 \mathrm{~mL}$ sterile Mueller-Hinton broth and placed into a shaking incubator at $37{ }^{\circ} \mathrm{C}$ for $24 \mathrm{~h}$. Resistance to antibiotics was determined by broth microdilution according to the Clinical and Laboratory Standards Institute (CLSI) standards for antimicrobial susceptibility testing [29]. CLSI Standards identify a resistance breakpoint concentration for each antibiotic, with bacterial growth above the identified concentration indicating a resistant organism. All screening was performed utilizing Sensititre ${ }^{\circledR}$ antimicrobic detection plates 
(TREK Diagnostic Systems, Inc., Cleveland, OH, USA), containing dilution ranges of sixteen widely utilized antibiotics (Table 1). Sensititre ${ }^{\circledR}$ broth microdilution antimicrobial susceptibility plates were introduced in 1980, and results have been shown to compare favorably to common cultivation-based susceptibility methods, including standardized broth microdilution, agar dilution, and disk diffusion [30]. Quality control was established utilizing E. faecalis (ATCC \#29212) in accordance with manufacturer guidelines. Loading of the plates was performed according to manufacturer's protocol, using $50 \mu \mathrm{L}$ of an Enterococcus isolate/Mueller-Hinton broth suspension in each well. Plates were sealed, and placed into a $37^{\circ} \mathrm{C}$ incubator for $24 \mathrm{~h}$.

Fluorescence of individual wells was read manually using a BioTek microplate reader (BioTek Instruments, Winooski, VT, USA). Positive and negative growth readings were ascertained by comparing negative and positive growth wells on the Sensititre ${ }^{\circledR}$ plate, and resistance was determined using established breakpoints (Table 1). Minimum inhibitory concentrations required to inhibit growth in $50 \%$ of the isolates $\left(\mathrm{MIC}_{50}\right)$ were calculated for each antibiotic using median resistance values and guidelines established in Schwarz et al. [31].

Table 1. Antibiotic concentrations pre-loaded on Sensititre ${ }^{\circledR}$ antimicrobic detection plates.

Except where noted, all target minimum inhibitory concentration (MIC) values are those established by the Clinical and Laboratory Standards Institute [29].

\begin{tabular}{|c|c|c|c|c|}
\hline Antibiotic & Abbreviation & Antibiotic Class & $\begin{array}{c}\text { Concentration } \\
\text { Range } \\
\left(\mu \mathrm{g} \cdot \mathbf{m L}^{-1}\right) \\
\end{array}$ & $\begin{array}{c}\text { Resistance } \\
\text { Breakpoint } \\
\left(\mu \mathrm{g} \cdot \mathrm{mL}^{-1}\right) \\
\end{array}$ \\
\hline Kanamycin & KAN & Aminoglycoside & $128-1024$ & $\geq 1024$ \\
\hline Linezolid & LZD & Oxazoladinone & $0.5-8$ & $\geq 8$ \\
\hline Lincomycin & LIN & Lincosamide & $1-8$ & $\geq 16$ \\
\hline Quinupristin/dalfopristin & SYN & Streptogramin & $0.5-32$ & $\geq 4$ \\
\hline Gentamicin & GEN & Aminoglycoside & $128-1024$ & $>500$ \\
\hline Tylosin tartrate & TYLT & Macrolide & $0.25-32$ & $\geq 32$ \\
\hline Vancomycin & VAN & Glycopeptide & $0.25-32$ & $\geq 32$ \\
\hline Daptomycin & DAP & Other & $0.25-16$ & $\geq 8$ \\
\hline Penicillin & PEN & B-lactam & $0.25-16$ & $\geq 16$ \\
\hline Chloramphenicol & CHL & Other & $2-32$ & $\geq 32$ \\
\hline Ciprofloxacin & CIP & Fluoroquinolone & $0.12-4$ & $\geq 4$ \\
\hline Tetracycline & TET & Tetracycline & $1-32$ & $\geq 16$ \\
\hline Erythromycin & ERY & Macrolide & $0.25-8$ & $\geq 8$ \\
\hline Tigecycline & TIG & Glycylcycline & $0.015-0.5$ & $>0.5^{a}$ \\
\hline Streptomycin & STR & Aminoglycoside & $512-2048$ & $>1024$ \\
\hline Nitrofurantoin & NIT & Other & 2-64 & $\geq 128$ \\
\hline
\end{tabular}

${ }^{a}$ European Committee on Antimicrobial Susceptibility Testing [25].

\subsection{Statistical Analysis}

Year-to-year differences in resistance and $\mathrm{MIC}_{50}$ were examined using paired t-tests. All statistical analyses were performed with Minitab ${ }^{\circledR}$ Release 16 Statistical Software (Minitab Inc., State College, PA, USA) using a significance level of $\alpha=0.05$. 


\section{Results}

\subsection{Antibiotic Resistance}

Selective enrichment of GRP inlet water samples revealed no viable Enterococcus, suggesting that microbial isolates examined in this study originated from natural reservoirs, and had not been deposited into the sediments directly with the reclaimed water.

Isolates from the 2009 and 2010 cores from the GRP showed no between-year differences in antibiotic resistance at any depth $(p=0.227, p=0.109$, and $p=0.529$ for $0-5,10-15$, and $25-50 \mathrm{~cm}$ cores, respectively). Isolates from the 2009 and 2010 MAC site also showed no between-year differences $(p=0.876, p=0.856$, and $p=0.806$ for $0-5,10-15$, and $15-50 \mathrm{~cm}$ cores, respectively). Thus, all findings below result from a dataset in which 2009 and 2010 isolates have been combined $(\mathrm{GRP}=264$ and $\mathrm{MAC}=134$ total enterococci $)$.

Resistance was defined as those isolates that were not inhibited at antibiotic concentrations equal to, or higher than, the target CLSI breakpoint (Table 1). Resistance to LIN was the most prevalent in Enterococcus isolates regardless of water treatment, with 60.6 and $70.1 \%$ of isolates resistant to LIN in the GRP and MAC sites, respectively (Table 2). Relatively equal resistance between sites was also found to TGC (9.1\% and 13.4\% resistant in GRP and MAC sites, respectively), PEN (7.6\% and 9.0\% resistant), DAP (16.7\% and 19.4\% resistant), VAN (6.1\% and 7.5\% resistant), SYN (15.2\% and 19.4\% resistant), and LZD (4.5\% resistant regardless of treatment). Resistance to STR and NIT was not found in any of the isolates from the GRP or MAC sediments. Isolates from MAC also revealed no resistance to CHL, GEN, or KAN, while GRP sediments showed low levels of resistance to all three of these antibiotics (3.0\%, 1.5\%, and 3.8\% resistant to CHL, GEN, and KAN, respectively).

Table 2. Rates of resistance to each antibiotic and concentrations of antibiotic needed to inhibit 50\% $\left(\mathrm{MIC}_{50}\right)$ of isolate growth in sediments recharged with treated wastewater or groundwater $(\mathrm{ND}=$ No resistance detected).

\begin{tabular}{|c|c|c|c|c|c|c|}
\hline \multirow[b]{2}{*}{ Antibiotic } & \multicolumn{3}{|c|}{ Treated Wastewater Sites } & \multicolumn{3}{|c|}{ Groundwater Sites } \\
\hline & $\begin{array}{c}\text { Total \# } \\
\text { Isolates }\end{array}$ & $\begin{array}{c}\text { Resistance } \\
\text { Rate (\%) }\end{array}$ & $\begin{array}{c}\mathrm{MIC}_{50} \\
\left(\mu \mathrm{g} \cdot \mathrm{mL}^{-1}\right)\end{array}$ & $\begin{array}{l}\text { Total \# } \\
\text { Isolates }\end{array}$ & $\begin{array}{c}\text { Resistance } \\
\text { Rate (\%) }\end{array}$ & $\begin{array}{c}\mathrm{MIC}_{50} \\
\left(\mu \mathrm{g} \cdot \mathrm{mL}^{-1}\right)\end{array}$ \\
\hline Kanamycin & 264 & 3.8 & $<128$ & 134 & ND & $<128$ \\
\hline Linezolid & 264 & 4.5 & 1 & 134 & 4.5 & 0.5 \\
\hline Lincomycin & 264 & 60.6 & 4 & 134 & 70.1 & 8 \\
\hline Quinupristin/dalfopristin & 264 & 15.2 & 0.5 & 134 & 19.4 & 0.5 \\
\hline Gentamicin & 264 & 1.5 & $<128$ & 134 & ND & $<128$ \\
\hline Tylosin tartrate & 264 & 2.3 & 0.5 & 134 & 13.4 & 2 \\
\hline Vancomycin & 264 & 6.1 & 2 & 134 & 7.5 & 1 \\
\hline Daptomycin & 264 & 16.7 & 2 & 134 & 19.4 & 1 \\
\hline Penicillin & 264 & 7.6 & 1 & 134 & 9.0 & 1 \\
\hline Chloramphenicol & 264 & 3.0 & 2 & 134 & ND & 4 \\
\hline Ciprofloxacin & 264 & 18.2 & 1 & 134 & 29.9 & 1 \\
\hline Tetracycline & 264 & 3.0 & 1 & 134 & 13.4 & 1 \\
\hline Erythromycin & 264 & 19.7 & 2 & 134 & 34.3 & 4 \\
\hline Tigecycline & 264 & 9.1 & 0.12 & 134 & 13.4 & 0.12 \\
\hline
\end{tabular}


Table 2. Cont.

\begin{tabular}{|c|c|c|c|c|c|c|}
\hline \multirow[b]{2}{*}{ Antibiotic } & \multicolumn{3}{|c|}{ Treated Wastewater Sites } & \multicolumn{3}{|c|}{ Groundwater Sites } \\
\hline & $\begin{array}{l}\text { Total \# } \\
\text { Isolates } \\
\end{array}$ & $\begin{array}{c}\text { Resistance } \\
\text { Rate (\%) }\end{array}$ & $\begin{array}{c}\mathrm{MIC}_{50} \\
\left(\mu \mathrm{g} \cdot \mathrm{mL}^{-1}\right)\end{array}$ & $\begin{array}{c}\text { Total \# } \\
\text { Isolates } \\
\end{array}$ & $\begin{array}{c}\text { Resistance } \\
\text { Rate (\%) }\end{array}$ & $\begin{array}{c}\mathrm{MIC}_{50} \\
\left(\mu \mathrm{g} \cdot \mathrm{mL}^{-1}\right)\end{array}$ \\
\hline Streptomycin & 264 & ND & $<512$ & 134 & ND & $<512$ \\
\hline Nitrofurantoin & 264 & ND & 8 & 134 & ND & 16 \\
\hline
\end{tabular}

\subsection{Multiple Antibiotic Resistance and Resistance Profiles}

Each Enterococcus isolate from the GRP and MAC sites was also assessed for the presence of resistance traits to multiple antibiotics (Figure 2). More than $25 \%$ of isolates from the GRP were susceptible to all antibiotics tested (no resistance detected), while fewer than $10 \%$ of the MAC isolates showed the same pattern. While resistance to a single antibiotic was slightly higher in isolates from the GRP, MAR (2 to 5) traits in single isolates were significantly ( $p=0.019)$ higher in the MAC isolates than in the GRP (Figure 2). Overall, the GRP enterococci showed an average of 1.6 resistance traits per isolate, and traits per isolate were slightly higher in the $0-5 \mathrm{~cm}$ sediments $(2.1$ resistance traits per isolate) than in the 10-15 cm (1.2) and 25-50 cm (1.8) depths. Compared to the GRP enterococci, the MAC isolates showed a slightly higher average of traits per isolate overall (2.1). In MAC isolates, traits were far higher in the $10-15 \mathrm{~cm}$ sediments (3.0) compared to the $0-5 \mathrm{~cm} \mathrm{(2.1)}$ and $25-50 \mathrm{~cm}$ (2.0) depths.

None of the patterns in MAR was dominant among the isolates; the most common pattern in resistance traits revealed was SYN-LIN, with $3.7 \%$ and $15.8 \%$ of the GRP and MAC isolates, respectively, resistant to only these two antibiotics. While two isolates from MAC showed resistance to as many as 7 antibiotics, one Enterococcus isolate from the $0-5 \mathrm{~cm}$ depth of GRP sediments showed resistance to 11 (TGC-ERY-CIP-CHL-PEN-DAP-VAN-TYLT-GEN-LIN-LZD) of the antibiotics tested.

Figure 2. Average number of resistance traits per isolate in Enterococcus isolates from treated wastewater (264 isolates) and groundwater (134 isolates) sediments.

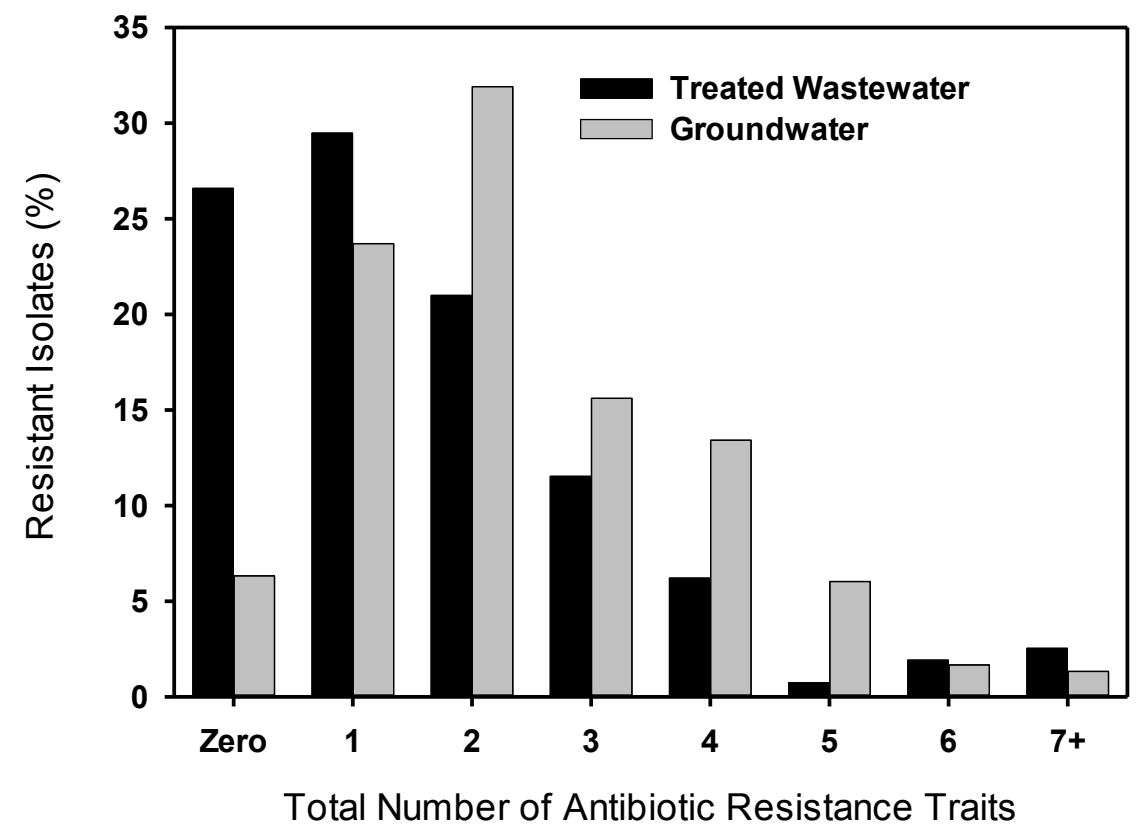




\section{3. $M I C_{50}$}

Identifying the $\mathrm{MIC}_{50}$ for the GRP and MAC isolates involved determining the breakpoint concentration for each antibiotic for each tested isolate, and then identifying the median of these values. Thus, in theory the $\mathrm{MIC}_{50}$ represents the concentration of each antibiotic necessary to inhibit growth of approximately $50 \%$ of the Enterococcus isolates [31]. No substantial differences in $\mathrm{MIC}_{50}$ values for antibiotics were identified between sites, though a general trend of higher $\mathrm{MIC}_{50}$ values were found in Enterococcus isolated from the groundwater-recharged sediments (Table 2). For example, concentrations of NIT necessary to inhibit $50 \%$ of Enterococcus growth in MAC sediments $\left(8 \mu \mathrm{g} \cdot \mathrm{mL}^{-1}\right)$ were double those required to inhibit the same growth levels in GRP enterococci $\left(4 \mathrm{~mL}^{-1}\right)$ (Table 2). For half of the tested antibiotics, $\mathrm{MIC}_{50}$ values for the GRP and MAC sediments were equal. Higher $\mathrm{MIC}_{50}$ values for GRP enterococci were found for 3 of the tested antibiotics, while higher values were found in MAC enterococci for 5 antibiotics tested.

\section{Discussion}

Many studies have shown that conventional WWTPs cannot remove antibiotics completely [3,4] and that these trace contaminants enter into the environment via effluent and sludge [32]. Recent experimental evidence has shown that subtherapeutic drug concentrations can enrich for resistant bacteria [33], suggesting that discharge of residual concentrations of antibiotics into natural environments may generate AR in native soil bacteria. In addition to trace levels of antibiotics, treated wastewater has also been shown to contain trace levels of heavy metals, detergents, and quaternary ammonium compounds, all of which have been linked to development of AR [34-36]. Lincomycin, the only antibiotic assayed at the GRP site, was present in water leaving the WWTP at levels averaging $5.0 \mathrm{ng} \cdot \mathrm{L}^{-1}$, while LIN concentrations in sediments ranged from $2.4 \times 10^{-3}$ to $7.6 \times 10^{-3} \mathrm{ng} \cdot \mathrm{g}^{-1}$ [37]. Although additional antibiotics were not assayed in the GRP water and sediment samples, the area surrounding the GRP is rich in human medical facilities. Within a $5 \mathrm{~km}$ distance are located 3 major medical centers and multiple urgent care facilities, surgery centers, and doctors' offices, supporting a strong possibility that, despite a high (tertiary) treatment level of the municipal wastewater, antibiotic residuals would be detectable in treated wastewater entering the GRP [38,39].

The presence of antibiotics in wastewater used for irrigation or recharge would support the hypothesis of AR development in environmental bacteria in the receiving basins [32,40,41]. Indeed, some studies report an increased incidence of AR among cultivated bacteria in raw sewage [13,42] and in surface water impacted by septic discharge [43]. Yet others find no such effects. Garcia-Armisen et al. [44] sampled rivers characterized by different levels of recent sewage pollution and found no relation between the level of sewage pollution and the proportion of AR in heterotrophic bacteria for any of the tested antimicrobials. Others warn that correlations between antibiotic concentrations and AR do not provide confirmation of a cause-effect relationship [5], pointing out that a correlation would be expected on the basis that both the antibiotics and bacterial isolates were derived from a common source, excreted by humans and discharged into the environment via sewage outfalls. Moreover, recent work has reported preferential elimination of non-resistant subsets of bacteria during wastewater 
treatment [45], suggesting that that the preferential elimination of susceptible organisms rather than their resistant counterparts may have an important contribution to AR increase.

Rates of AR to individual antibiotics found in this study (regardless of treatment), agree with those reported in similar work. Our finding of $>60 \%$ resistance rates to LIN in both GRP and MAC sediments is not unprecedented, as intrinsic resistance to LIN among the enterococci has been reported in other studies [46,47]. In an assessment of AR Enterococcus in wastewater and domestic animals in Canada, Klare et al. [47] reported that more than 55\% of isolates were resistant to LIN at both breakpoint and twice breakpoint concentrations. In their study of antimicrobial-resistant enterococci from secondary effluent in a WWTP in Poland, Luczkiewicz [48] found rates of AR similar to GRP sites for several antibiotics, including GEN (6\%), VAN (6\%), and LZD (9\%); but higher levels of resistance to ERY (41\%), STR (9\%), and NIT (62\%). Servais and Passerat [49] surveyed 148 Enterococcus isolates from the Seine River (France) and reported AR rates similar to the GRP and MAC sites, including CHL (4\%), LZD (8\%), but higher levels of resistance to ERY (49\%) and TET (18\%). In addition, Servais and Passerat reported that $83 \%$ of enterococci were resistant to at least one antibiotic, while $49 \%$ were MAR, similar to GRP sites (73.5\% AR, 44.0\% MAR) but lower than resistance levels found in MAC enterococci (93.7\% AR, 70.0\% MAR).

Our finding of a wide range in resistance profiles of enterococci was also not unprecedented. Brown and Balkwill [20] found 83 distinct profiles among the 138 resistant bacterial strains isolated from the deep subsurface. Five strains were resistant to ampicillin, but no other distinct profiles were shared by more than 2 strains. D'Costa et al. [19] reported 69 distinct profiles among 537 Streptomyces isolates from wastewater and sludge. The number of resistance traits per isolate (average 1.6 for GRP; 2.1 for MAC) are slightly lower than reported by Abriouel et al. [50] in their survey of bacteria isolates from surface waters, wells, and municipal wastewater in in Spain (3.1-3.7 resistance traits per isolate), but this may be due to methodological differences, such as antibiotics assayed, between the two studies.

It is clear that the inclusion of the MAC control site receiving no treated wastewater was critical to the findings of this study. While analysis of the cultivable fraction of Enterococcus in sediments exposed to long-term recharge with recycled municipal wastewater showed AR at levels similar to that found in the scientific literature, there was no discernible increase in AR when compared to enterococci isolated from groundwater-recharged sediments. These results, along with the finding of strikingly lower MAR in sediments from the wastewater-recharged sites suggest an increased, rather than the hypothesized decreased [51], susceptibility to antibiotics in Enterococcus following long-term exposure to wastewater. This trend was also supported by the higher $\mathrm{MIC}_{50}$ values for 5 antibiotics found in isolates from the groundwater-recharged sediments. Kohanski et al. [52] reported that treatment with low concentrations of antibiotics, such as that found in treated wastewater, can increase bacterial $\mathrm{MIC}_{50}$, but MAC sediments did not support this tendency.

Ours is not the first study to utilize culture-based isolate methods to conclude that treated wastewater does not amplify AR in soils. Negreanu et al. [53] reported high levels of AR in both freshwater and wastewater-irrigated soils in Israel, but also found that AR bacteria in wastewater-irrigated soils were on the whole identical, or even lower, than those under freshwater-irrigation. They concluded that the impact of the treated wastewater-associated bacteria on the soil resistome was negligible.

Little is known about the antibiotic resistomes of the vast majority of environmental bacteria, although there have been calls for a greater understanding of the environmental reservoirs of AR and 
their potential impacts on clinically important bacteria [54,55]. It is becoming increasingly clear that some environments harbor AR genes irrespective of the human use of antibiotics, and the literature abounds with cases of persistence of AR genes in apparently antibiotic-free environments. Lima-Bittencourt et al. [56] found that the phenotype of more than $60 \%$ of the Enterobacteriaceae isolates from the pristine freshwater environments was found to be MAR, while Brown and Balkwill [20] screened isolates from subsurface (170-250 m below surface) environments and reported that more than $70 \%$ of the bacteria were MAR. Perhaps most revealing, D'Costa et al. [57] analyzed ancient DNA extracted from 30,000-year old permafrost sediments and reported the identification of a diverse collection of genes encoding resistance to beta-lactam, tetracycline, and glycopeptide antibiotics. Their results show conclusively that $\mathrm{AR}$ is a natural phenomenon that predates the modern selective pressure of clinical antibiotic use.

What remains somewhat unclear is the function of a "natural" antibiotic resistome in sediments. It has been suggested that naturally-occurring antibiotics might serve as signaling molecules at the low concentrations in which they are usually found in natural habitats [58,59]. This suggestion is based on the fact that low concentrations of antibiotics trigger specific transcriptional changes that can be beneficial for the microorganisms involved [60]. A second hypothesis for the primary ecological role for naturally-produced antibiotics is that they may function in inhibiting the growth of other organisms in soils, thus alleviating competition for scarce resources [16].

The hypothesis that a primary ecological role for naturally-produced antibiotics is likely to be in inhibiting the growth of competitors may support our observed reduction in MAR in GRP sediments. Levels of organic carbon in surface $(0-5 \mathrm{~cm})$ layer of GRP sediments averaged $0.43 \%$, compared to a typical organic carbon content for the surface layer of Arizona sediments of $<0.25 \%$ [37]. This would indicate that the long-term application of treated wastewater increased the organic carbon of the top $5 \mathrm{~cm}$ of sediments by an average of more than $70 \%$. Dissolved organic carbon represents the main source of energy-rich carbon substrates for soil microorganisms [61,62]. Given such a substantial increase in substrate availability, it is feasible that over time, bacteria in GRP sediments experienced a reduction in resource competition, and an associated reduction in the need for antibiotic production. The maintenance of AR is energetically expensive to bacteria [63] and long-term reductions in competition could hypothetically reduce the necessity for antibiotic production and expression of AR genes. Of course, this is only one theory related to an undoubtedly very complex phenomenon, and requires further examination.

A substantial caveat to the results of this study is that they depend entirely on our analysis of cultivable, aerobic bacteria, which is well known to represent but a minor fraction of the total bacterial community [64]. Auerbach et al. [13] contend that any cultivation-based approach likely provides a significant underestimation of the total pool of AR organisms present in complex microbial communities such as those found in WWTPs and aquatic ecosystems. However, such cultivation bias would clearly exist in sediments impacted or not impacted by treated wastewater. Perhaps an equally significant bias would be presented by molecular-based approaches to identification of resistance genes, in that they do not exclude DNA from dead bacterial cells, strongly suggesting that the cultivable fraction must be considered in well-designed studies of the development of AR. The establishment of standard international guidelines for assessment of environmental AR, based on both molecular and cultural mechanisms, might represent a step forward for further risk analysis. 


\section{Conclusions}

Because treated wastewater has been shown in multiple studies to potentially contain trace levels of antibiotic compounds, long-term application of these waters to the environment might hypothetically induce resistance in soil bacteria. However, our cultivation-based results showed that levels of bacterial AR in sediments undergoing long-term recharge with treated wastewater were high, but were equal to levels found in sediments with no exposure to treated wastewater. Furthermore, bacterial MAR in sediments from groundwater-filled ponds was significantly higher than MAR in wastewater-exposed sediments. This work suggests that the natural resistome is significant in soils, and validates that the finding of resistant organisms in a given environment should not necessarily be considered as evidence of pollution by antibiotics or by resistance genes.

Very few data exist on the long-term effects of environmental pollution with antibiotics and AR bacteria. A thorough understanding of the molecular and cultural mechanisms involved in the emergence and dissemination of AR, careful experimental validation, and enhanced surveillance systems are essential for assessing the safety and public health impacts of recharge with treated wastewater.

\section{Acknowledgments}

This research was supported by the United States Department of Agriculture, Agricultural Research Service, National Program \#211, Water Availability and Watershed Management. We also acknowledge the field and technical assistance of Allan Knopf and Colin Breslin, and the laboratory assistance of Matthew Hagler and Sharette Colbert.

\section{Author Contributions}

Jean E. McLain supervised all field collections of sediments at the MAC control sites, and supervised all microbiological laboratory analyses reported in this manuscript. She served as primary author, performing all data analyses, literature review, and writing of all drafts. Clinton F. Williams supervised field collections of soil cores at the GRP site, and supervised assays for soil chemical and physical properties reported herein. He served as secondary author, providing significant input on all drafts of the manuscript. Both authors were equally responsible for planning and execution of the field studies, and funding the completion of the project.

\section{Conflicts of Interest}

The authors declare no conflict of interest.

\section{References}

1. WHO (World Health Organization). WHO Annual Report on Infectious Disease: Overcoming Antimicrobial Resistance. Available online: http://www.who.int/infectious-disease-report/2000/ (accessed on 20 January 2014). 
2. Böckelmann, U.; Dörries, H.-H.; Ayuso-Gabella, M.N.; de Marçay, M.S.; Tandoi, V.; Levantesi, C.; Masciopinto, C.; van Houtte, E.; Szewzyk, U.; Wintgens, T.; et al. Quantitative PCR monitoring of antibiotic resistance genes and bacterial pathogens in three European artificial groundwater recharge systems. Appl. Environ. Microbiol. 2009, 75, 154-163.

3. Miao, X.S.; Bishay, F.; Chen, M.; Matcalfe, C.D. Occurrence of antimicrobials in the final effluents of wastewater treatment plants in Canada. Environ. Sci. Technol. 2004, 38, 3533-3541.

4. Göbel, A.; Thomsen, A.; McArdell, C.S.; Joss, A.; Giger, W. Occurrence and sorption behavior of sulfonamides, macrolides, and trimethoprim in activated sludge treatment. Environ. Sci. Technol. 2005, 39, 3981-3989.

5. Jury, K.L.; Khan, S.J.; Vancov, T.; Stuetz, R.M.; Ashbolt, N.J. Are sewage treatment plants promoting antibiotic resistance? Crit. Rev. Environ. Sci. Technol. 2011, 41, 243-270.

6. Cha, J.M.; Yang, S.; Carlson, K.H. Trace determination of $\beta$-lactam antibiotics in surface water and urban wastewater using liquid chromatography combined with electrospray tandem mass spectrometry. J. Chromatogr. A 2006, 1115, 46-57.

7. Göbel, A.; McArdell, C.S.; Joss, A.; Siegrist, H.; Giger, W. Fate of sulfonamides, macrolides, and trimethoprim in different wastewater treatment technologies. Sci. Total Environ. 2007, 372, 361-371.

8. Lindberg, R.H.; Wennberg, P.; Johansson, M.I.; Tysklind, M.; Andersson, B.A.V. Screening of human antibiotic substances and determination of weekly mass flows in five sewage treatment plants in Sweden. Environ. Sci. Technol. 2005, 39, 3421-3429.

9. Karthikeyan, K.G.; Meyer, M.T. Occurrence of antibiotics in wastewater treatment facilities in Wisconsin, USA. Sci. Total Environ. 2006, 361, 196-207.

10. Kolpin, D.W.; Furlong, E.T.; Meyer, M.T.; Thurman, E.M.; Zaugg, S.D.; Barber, L.B.; Buxton, H.T. Pharmaceuticals, hormones, and other organic wastewater contaminants in US streams, 1999-2000: A national reconnaissance. Environ. Sci. Technol. 2002, 36, 1202-1211.

11. Yang, S.; Carlson, K.H. Evolution of antibiotic (tetracyclines and sulfonamides) occurrence in a river through pristine, urban and agricultural landscapes. Water Res. 2003, 37, 4645-4656.

12. Pauwels, B.; Verstraete, W. The treatment of hospital wastewater: An appraisal. J. Water Health 2006, 4, 405-416.

13. Auerbach, E.A.; Seyfried, E.E.; McMahon, K.D. Tetracycline resistance genes in activated sludge wastewater treatment plants. Water Res. 2007, 41, 1143-1151.

14. Giger, W.; Alder, A.C.; Golet, E.M.; Kohler, H.E.; McArdell, C.S.; Molnar, E.; Siegrist, H.; Suter, M.F. Occurrence and fate of antibiotics as trace contaminants in wastewaters, sewage sludges, and surface waters. Chimia 2003, 57, 485-491.

15. Dhanapal, L.P.; Morse, A.N. Effect of analgesics and their derivatives on antibiotic resistance of environmental microbes. Water Sci. Technol. 2009, 59, 1823-1829.

16. Waksman, S.A.; Woodruff, H.B. The soil as a source of microorganisms antagonistic to disease-producing bacteria. J. Bacteriol. 1940, 40, 581-600.

17. Martin, M.F.; Liras. P. Organization and expression of genes involved in the biosynthesis of antibiotics and other secondary metabolites. Annu. Rev. Microbiol. 1989, 43, 173-206.

18. Hopwood, D.A. How do antibiotic-producing bacteria ensure their self-resistance before antibiotic biosynthesis incapacitates them? Mol. Microbiol. 2007, 63, 937-940. 
19. D’Costa, V.M.; McGrann, K.M.; Hughes, D.W.; Wright, G.D. Sampling the antibiotic resistome. Science 2006, 311, 374-377.

20. Brown, M.G.; Balkwill, D.L. Antibiotic resistance in bacteria isolated from the deep terrestrial subsurface. Microb. Ecol. 2009, 57, 484-493.

21. Hayes, J.R.; English, L.L.; Carr, L.E.; Wagner, D.D.; Joseph, S.W. Multiple-antibiotic resistance of Enterococcus spp. isolated from commercial poultry production environments. Appl. Environ. Microbiol. 2004, 70, 6005-6011.

22. Giard, J.C.; Laplace, J.M.; Rince, A.; Pichereau, V.; Benachour, A.; Leboeuf, C.; Flahaut, S.; Auffray, Y.; Artke, A. The stress proteome of Enterococcus faecalis. Electrophoresis 2001, 22, 2947-2954.

23. Kühn, I.; Iversen, A.; Burman, I.G.; Olsson-Liljequist, B.; Franklin, A.; Finn, M.; Aarestrup, F.; Seyfarth, A.M.; Blanch, A.R.; Taylor, H.; et al. Epidemiology and ecology of enterococci, with special reference to antibiotic resistant strains in animals, humans, and the environment. Example of an ongoing project within the European research programme. Int. J. Antimicrob. Agents 2000, 14, 337-342.

24. Kayser, F.H. Safety aspects of enterococci from the medical point of view. Int. J. Food Microbiol. 2003, 88, 255-262.

25. EUCAST (European Committee on Antimicrobial Susceptibility Testing) Steering Committee. EUCAST technical note on tigecycline. Clin. Microbiol. Infec. 2006, 12, 1147-1149.

26. He, J.-W.; Jiang, S. Quantification of enterococci and human adenovirus in environmental samples by real-time PCR. Appl. Environ. Microbiol. 2005, 71, 2250-2255.

27. Post, D.F.; Mack, C.; Camp, P.D.; Suliman, A.S. Mapping and characterization of the soils on the University of Arizona Maricopa Agricultural Center. J. Ariz.-Nev. Acad. Sci. 1988, 18, 49-60.

28. Harper, W.G.; Youngs, F.O.; Strahorn, A.T.; Armstrong, S.W.; Schwalen, H.C. Soil survey of the Salt River Valley Area, Arizona; U.S. Department of Agriculture Bureau of Chemistry and Soils: Washington, DC, USA, 1926.

29. CLSI (Clinical and Laboratory Standards Institute). Performance Standards for Antimicrobial Susceptibility Testing; Twentieth Informational Supplement; Document M100-S20; CLSI: Wayne, PA, USA, 2010.

30. Chapin, K.C.; Musgnug, M.C. Validation of the automated reading and incubation system with Sensititre ${ }^{\circledR}$ plates for antimicrobial susceptibility testing. J. Clin. Microbiol. 2003, 41, 1951-1956.

31. Schwarz, S.; Silley, P.; Simjee, S.; Woodfords, N.; van Duijkeren, E.; Johnson, A.P.; Gaastra, W. Assessing the antimicrobial susceptibility of bacteria obtained from animals. J. Antimicrob. Chemoth. 2010, 65, 601-604.

32. Kim, S.; Aga, D.S. Potential ecological and human health impacts of antibiotics and antibiotic-resistant bacteria from wastewater treatment plants. J. Toxicol. Environ. Health Part B 2007, 10, 559-573.

33. Gullberg, E.; Cao, S.; Berg, O.G.; Ilback, C.; Sandegren, L.; Hughes, D.; Andersson, D.I. Selection of resistant bacteria at very low antibiotic concentrations. PLoS Pathog. 2011, 7, e1002158.

34. Silver, S.; Phung, L.T. Bacterial heavy metal resistance: New surprises. Annu. Rev. Microbiol. 1996, 50, 753-789. 
35. Alonso, A.; Sanchez, P.; Martinez, J.L. Environmental selection of antibiotic resistance genes. Environ. Microbiol. 2001, 3, 1-9.

36. Baker-Austin, C.; Wright, M.S.; Stepanauskas, R.; McArthur, J.V. Co-selection of antibiotic and metal resistance. Trends Microbiol. 2006, 14, 176-182.

37. Williams, C.F.; McLain, J.E.T. Soil persistence and fate of carbamazepine, lincomycin, caffeine, and ibuprofen from wastewater reuse. J. Environ. Qual. 2012, 41, 1473-1480.

38. Brown, K.D.; Kulis, J.; Thomson, B.; Chapman, T.H.; Mawhinney, D.B. Occurrence of antibiotics in hospital, residential, and dairy effluent, municipal wastewater, and the Rio Grande in New Mexico. Sci. Total Environ. 2006, 366, 772-783.

39. Diwan, V.; Lundborg, C.S.; Tamhanka, A.J. Seasonal and temporal variation in release of antibiotics in hospital wastewater: Estimation using continuous and grab sampling. PLoS One 2013, 8, 1-7.

40. Andersen, S.R. Effects of waste water treatment on the species composition and antibiotic resistance of coliform bacteria. Curr. Microbiol. 1993, 26, 97-103.

41. Galvin, S.; Boyle, F.; Hickey, P.; Vellinga, A.; Morris, D.; Cormican, M. Enumeration and characterization of antimicrobial-resistant Escherichia coli bacteria in effluent from municipal, hospital, and secondary treatment facility sources. Appl. Environ. Microbiol. 2010, 76, 4772-4779.

42. Reinthaler, F.F.; Posch, J.; Feieri, G.; Wust, G.; Haas, D.; Ruckenbauer, G.; Mascher, F.; Marth, E. Antibiotic resistance of $E$. coli in sewage and sludge. Water Res. 2003, 37, 1685-1690.

43. Harwood, V.J.; Whitlock, J.; Withington, V. Classification of antibiotic resistance patterns of indicator bacteria by discriminant analysis use in predicting the source of fecal contamination in subtropical waters. Appl. Environ. Microbiol. 2000, 66, 3698-3704.

44. Garcia-Armisen, T.; Vercammen, K.; Passerat, J.; Triest, D.; Servais, P.; Cornelis, P. Antimicrobial resistance of heterotrophic bacteria in sewage-contaminated rivers. Water Res. 2011, 45, 788-796.

45. Figueira, V.; Serra, E.; Manaia, C.M. Differential patterns of antimicrobial resistance in population subsets of Escherichia coli isolated from waste- and surface waters. Sci. Total Environ. 2011, 409, 1017-1023.

46. Murray, B.E. The life and times of the Enterococcus. Clin. Microbiol. Rev. 1990, 3, 46-65.

47. Klare, I.; Konstabel, C.; Badstübner, D.; Werner, G.; Witte, W. Occurrence and spread of antibiotic resistances in Enterococcus faecium. Int. J. Food Mirobiol. 2003, 88, 269-290.

48. Luczkiewicz, A.; Jankowska, K.; Bray, R.; Kulbat, E.; Quant, B.; Sokolowska, A.; Olanczuk-Neyman, K. Antimicrobial resistance of fecal indicators in disinfected wastewater. Water Sci. Technol. 2011, 64, 2352-2361.

49. Servais, P.; Passerat, J. Antimicrobial resistance of fecal bacteria in waters of the Seine river watershed (France). Sci. Total Environ. 2009, 408, 365-372.

50. Abriouel, H.; Omar, N.B.; Molinos, A.C.; López, R.L.; Grande, M.J.; Martinez-Viedma, P.; Ortega, E.; Cañamero, M.M.; Galvez, A. Comparative analysis of genetic diversity and incidence of virulence factors and antibiotic resistance among enterococcal populations from raw fruit and vegetable foods, water and soil, and clinical samples. Int. J. Food Microbiol. 2008, 123, 38-49.

51. Andrews, J.M. Determination of minimum inhibitory concentrations. J. Antimicrob. Chemother. 2001, 48, 5-16. 
52. Kohanski, M.A.; DePristo, M.A.; Collins, J.J. Sublethal antibiotic treatment leads to multidrug resistance via radical-induced mutagenesis. Mol. Cell 2010, 37, 311-320.

53. Negreanu, Y.; Pasternak, A.; Jurkevitch, E.; Cytryn, E. Impact of treated wastewater irrigation on antibiotic resistance in agricultural soils. Env. Sci. Technol. 2012, 46, 4800-4808.

54. Rosenblatt-Farrell, N. The landscape of antibiotic resistance. Environ. Health Perspect. 2009, 117, A244-A250.

55. American Academy of Microbiology (AAM). Antibiotic Resistance: An Ecological Perspective to an Old Problem; AAM: Washington, DC, USA, 2009.

56. Lima-Bittencourt, C.I.; Cursino, L.; Gonçalves-Dornelas, H.; Pontes, D.S.; Nardi, R.M.; Callisto, M.; Chartone-Souza, E.; Nascimento, A.M.A. Multiple antimicrobial resistance in Enterobacteriaceae isolates from pristine freshwater. Genet. Mol. Res. 2007, 6, 510-521.

57. D’Costa, V.M.; King, C.F.; Kalan, L.; Morar, M.; Sung, W.W.L.; Schwarz, C.; Froese, D.; Zazula, G.; Calmels, F.; Debruyne, R.; et al. Antibiotic resistance is ancient. Nature 2011, 477, 457-461.

58. Davies, J. Are antibiotics naturally antibiotics? J. Ind. Microbiol. Biotechnol. 2006, 33, 496-499.

59. Fajardo, A.; Martinez, J.L. Antibiotics as signals that trigger specific bacterial responses. Curr. Opin. Microbiol. 2008, 11, 161-167.

60. Linares, J.F.; Gustafsson, I.; Baquero, F.; Martinez, J.L. Antibiotics as inter-microbial signaling agents instead of weapons. Proc. Natl. Acad. Sci. USA 2006, 103, 19484-19489.

61. Wardle, D.A. A comparative assessment of the factors which influence microbial biomass carbon and nitrogen levels in soil. Biol. Rev. 1992, 67, 321-358.

62. Neff, J.C.; Asner, G.P. Dissolved organic carbon in terrestrial ecosystems: Synthesis and a model. Ecosystems 2001, 4, 29-48.

63. Martinez, J.L.; Rojo, F. Metabolic regulation of antibiotic resistance. FEMS Microbiol. Rev. 2011, 35, 768-789.

64. Amman, R.I.; Ludwig, W.; Schleifer, K.H. Phylogenetic identification and in situ detection of individual microbial cells without cultivation. Microbiol. Rev. 1995, 59, 143-169.

(C) 2014 by the authors; licensee MDPI, Basel, Switzerland. This article is an open access article distributed under the terms and conditions of the Creative Commons Attribution license (http://creativecommons.org/licenses/by/3.0/). 